\title{
Foreign Direct Investment and Economic Growth: Evidence from Sri Lanka
}

\author{
Thirunavukkarasu Velnampy ${ }^{1}$, Sivapalan Achchuthan ${ }^{2}$, \& Rajendran Kajananthan ${ }^{3}$ \\ ${ }^{1}$ University of Jaffna, Sri Lanka \\ ${ }^{2}$ Sabaragamuwa University of Sri Lanka, Sri Lanka \\ Correspondence: Sivapalan Achchuthan, Faculty of Management studies, Sabaragamuwa University of Sri \\ Lanka, Sri Lanka. E-mail: achchu2009@gmail.com
}

Received: October 28, 2013

Accepted: November 12, 2013

Online Published: December 15, 2013

doi:10.5539/ijbm.v9n1p140

URL: http://dx.doi.org/10.5539/ijbm.v9n1p140

\begin{abstract}
Various international organizations and foreign advisors suggested that developing countries should focus primarily on foreign direct investment (FDI) as a source of external finance. In this context, the main purpose of the study is to find out the impact of foreign direct investment on economic growth in the Sri Lankan Perspective. Data on the foreign direct investment and economic growth from the year 1990 to 2011 were collected for the study purpose. Further, the results revealed that, there is no significant impact of FDI on the economic growth, which is in lowest level. Only 4.3 percent of the variance in the dependent variable has been found. In contrast, we found that, in the Sri Lankan context, there is a long run equilibrium relationship between FDI and economic growth rate. Statistical findings on the basic regression analysis, Co integration test and Granger causality test show the contradiction in terms of the findings. Meantime, scholars in the econometrics stated that, Co integration test generally is applied among time series data. Due to that, Co integration test give the insights to the findings in terms of long run view. Finally, we have suggested that, the Sri Lankan Government and Central Bank of Sri Lanka jointly should take the necessary action to focus on the infrastructure development through the FDI to get the economic growth in the long term view. Meantime, FDI should be directed to agricultural actives to get the food sufficient aspects in the local and globalized level.
\end{abstract}

Keywords: economic growth, foreign direct investment, Sri Lankan economic perspective

\section{Background of the Study}

According to the International Monetary Fund and Organization for Economic Co-operation Development, the FDI is defined as an international venture in which an investor residing in the home economy acquires a long-term "influence" in the management of an affiliate firm in the host economy. European Union Report on International trade and foreign direct investment, 2013 stated that, The Globalization has the impact on the economy through the foreign trade in goods and services, financial flows and the movement of persons linked to cross - border economic activity. Further, there are two main sources of trade statistics: the first is international trade in goods statistics which provide highly detailed information on the value and quantity of international trade; the second is balance of payments statistics which register all the transactions of an economy with the rest of the world. In 2002, Organization for Economic Co-operation Development (OECD) suggested that FDI has the favorable climate in terms of economic growth, employment opportunities and poverty alleviation in an economy. But the achievements of the above mentioned favorable climate generally depend on the various economic, social and political factors. In the economic factors, the financial system stability, better integration of financial intermediaries, appropriate fiscal and monetary policy, interdependence between the economic sectors, well established connection between domestic and foreign trade are recognized as the influencing factors on the FDI.

According to the United Nation Report on the Global Investment Trends Monitor, 2013, Global foreign direct investment (FDI) inflows have been declined by $18 \%$ in 2012, to an estimated US $\$ 1.3$ trillion. The strong declining trend in the FDI flows influence the other macro economic variables as Gross Domestic Product (GDP), trade balance, fiscal deficit, and price level and employment growth in an economy. In the majority of European Countries, the FDI flows have been declined drastically with the total fall amounting to some US\$150 billion in 2012. In Sri Lanka, before the government implemented the economic liberalization policy, economy 
followed the inward looking policies, which had limitations for foreign investors and free flow of FDI. Later, implementation of the economic liberalization in Sri Lanka created the friendly economic climate. And also, Sri Lanka was one of the longest democratic traditions in the region and over the years, governments have followed free market policies and continued to liberalize the economy. Further, Sri Lanka creates better economic environment to attract the FDI through the monetary and fiscal policy framework in South Asian region (Athukorala, 2013).

In the Sri Lankan Perspective, in Sri Lanka, the period between 1960-1976 has been considered as the period which had the poor economic performance in terms of lower average economic growth rate. Especially, Period from 1970-1976 has been viewed as period which had economic recession. This period is especially well known as the most trade restricted period of the economy. After that, the liberalization policy was adopted to the economy. As results of the liberalization policy, the economic growth rate was increased dramatically. Further, in the period of 1987-89, economic growth rate was affected by the political instability. Later, in 2001, negative growth level has been faced by the economy. Again the Political instability was the reason for the particular economic recession. . However as a whole, country has performed well after 1977 with compared to the period before 1977. Meantime, Sri Lankan economy has achieved the 5 percentage growth level approximately for recent four decades. This level is the satisfactory one in the South Asian Region. Growth rate has been steadily increased for last decade (2000-2010). Further, in the Asian region, china and India have already achieved the 8 percentage growth level. And also output gap between advanced and emerging economies has been narrowing over the past decade and is expected to narrow even further going forward ( Sri Lankan Economic Outlook, 2012; Velnampy \& Achchuthan, 2013a; Velnampy \& Achchuthan, 2013b; Hearth).

Therefore, it is important to empirically examine the impact of FDI on economic growth and unemployment in the Sri Lankan perspective. Such understanding or finding will help to policy makers to establish the better policy framework in the foreign direct investment in the developing or emerging economy like Sri Lanka.

\subsection{Research Question Is Formulated}

RQ 1: What extent the foreign direct investment influences on economic growth in the Sri Lankan Perspective?

The main objective of the study is to find out the impact of foreign direct investment on economic growth.

Secondary objectives are:

- To show the trend of foreign direct investment and Economic growth;

- $\quad$ To find out the long run relationship between foreign direct investment and economic growth;

- To find out the causal relationship between foreign direct investment and economic growth;

- $\quad$ To suggest the Policy makers to formulate the better policy frame work in the foreign direct investment to enhance the economic growth in the developing countries perspective.

\section{Review of Literature}

Foreign Direct Investment (FDI) can be explained as the investment which is being invested by an investor in foreign countries with interest to gain more market share in the international context and enjoy the economies of scale (Shaari, Hong \& Shukeri, 2012). Further, FDI provides the basic infrastructure facilities to the developing countries (host countries) to enhance the entrepreneurial intention and eliminate the poverty in terms of better standard of living (Athukorala, 2013).

Denisia (2010) noted that Foreign Direct Investment (FDI) gained crucial role in the international business after the Second World War. Economic mechanism and the behavior of economic agents have been explained by Theoretical studies on FDI. Further, he stated that, theories in the FDI can be categorized in to four, such as Production Cycle Theory in the FDI, The Theory of Exchange Rates on Imperfect Capital Markets, The Internalization Theory and The Eclectic Paradigm.

Production Cycle Theory in the Foreign Direct Investment has been formulated by the Vernon in 1966. He used this theory to explain the certain types of foreign direct investment made by U.S. companies in Western Europe after the Second World War in the manufacturing industry. According to the theory, after the Second World War 2, USA companies began to export the goods with the advantage of technology among international competitors to the Western Europe countries. Meantime, demand for the USA goods has also been increased in Western Europe countries. Later, European firms have started imitating American products. Due to that, US companies have utilized the strategic economic concept as FDI which established the production facilities in the Europe to maintain the market shares. The Internalization Theory, which has been developed by Buckley and Casson in 1976 and tried to explain the growth of transnational companies and their motivations for achieving 
foreign direct investment. Further, the Eclectic Paradigm is considered as the integrated theory in the FDI concept, which has been established and developed by Dunning (1988). Researcher integrated the three strategic concepts as ownership, Location and internationalization. In the ownership advantage, the transnational companies should have the advantage to enter in to the foreign market in terms of competences (Denisia ,2010).

Various international organizations and foreign advisors suggested that developing countries should focus primarily on foreign direct investment (FDI) as a source of external finance. Generally, FDI induces economic growth more than other types of capital inflows. In particular, FDI is supposed to be less volatile, and to offer not just capital but also access to modern technology and know-how (Nunnenkamp and Spatz, 2009). The results on the FDI and its impact on economic growth are in mixed context. Ram and Zhang (2002) focused on foreign direct investment and economic growth in the cross-country level. They found the significant positive influence between FDI and economic growth. In contrast, Carkovic and Levine (2002) have found the insignificant influence. Further, Dutt (1977) has found that, there is a significant negative impact of FDI on economic growth. Further, the empirical findings seem to become clearer once host economy Characteristics in terms of economical, social, cultural and political factors is taken into account. Blomstom, Lipsey and Zejan (1994) noted that FDI has the significant impact on the economic growth. The finding is limited to the developing countries which are in the higher income perspective. Borensztein, Gregorio and Lee (1998) have found that FDI enhances growth only in economies with a sufficiently qualified labor force.

Alfaro, Chanda, Ozcan and Sayek (2003) examined the various links among foreign direct investment (FDI), financial markets, and economic growth using cross-country data between 1975-1995. They rationalized that; the FDI can contribute to the economic growth. Meantime, the financial system of the economy also influences on the linkage between FDI and economic growth. In other words, if there is financial system stability in the economy, the economic growth will be contributed by the FDI effectively and efficiently. Further, in the host countries perspective, they stated the benefits of the FDI as utilization of the resources, introduction of new process to the domestic market, learning-by-observing, networks, training of the labor force etc. researchers finally suggested to get the financial system stability through the better monetary and fiscal policy to attract the FDI. They also rationalized that, the FDI which will be attracted by the financial system stability generally contributes to the prosperity of the economy in terms of quality of the people in the country.

Tim Bu and Milner (2008) examined the study on the Foreign Direct Investment into Developing Countries. They found that, International trade agreements and preferential trade agreements have great impact or influence on the FDI inflows in the developing countries. Due to that, joining with international trade agreements induce to attract the FDI. Finally, the increasing trends of the FDI through joining with international trade agreements enhance the economic growth level of the developing countries. Further, Khaliq and Noy (2007) conducted the study on Foreign Direct Investment and Economic Growth. Researchers found that, In the aggregate level, FDI is observed to have a positive effect on economic growth. However, positive effect has not been found in the separate context across the sectors. Some sectors saw the positive impact of FDI, while mining and quarrying saw the negative impact of FDI inflows on the growth.

Based on above theoretical and empirical review, we have developed the following hypotheses:

\section{Methods and Hypotheses}

\subsection{Data Collection}

Secondary data which are collected from the Central bank reports of Sri Lanka have been utilized in this study. Further, textbooks, journals, magazines in the economic perspective were utilized for this study.

\subsection{Sample}

This study was conducted in Sri Lankan perspective, especially on the foreign direct investment and economic growth. Data on the foreign direct investment and economic growth from the year 1990 to 2011 were collected for the study purpose.

\subsection{Models of the Study}

In this study, economic growth is a function of the foreign direct investment

$$
E G=\beta o+\beta 1 F D I+\varepsilon i
$$

Where:

$\beta o=$ Intercept.

$\beta 1=$ Population slope. 
$E G=$ Economic Growth.

FDI $=$ Foreign Direct Investment.

$\varepsilon i=$ Random Error.

$$
\ln E G t=\beta 0+\beta 1 \ln F D I t+\varepsilon t
$$

Where:

$\mathrm{EG} t=$ Real Gross Domestic Production in the period $\mathrm{t}$.

FDI $\mathrm{t}=$ Foreign Direct Investment in period $\mathrm{t}$.

\subsection{Hypotheses Developments}

$\mathrm{H}_{1}$ : Foreign direct investment has significant impact on economic growth.

$\mathrm{H}_{2}$ : There is a significant Long run Relationship between foreign direct investment and economic growth.

$\mathrm{H}_{3}$ : There is a Causal Relationship between foreign direct investment and economic growth.

\subsection{Data analysis Method}

In this study, Economic growth in terms of Real GDP Growth rate is considered as dependent variable and foreign direct investment (FDI) in terms of Growth rate in USA Dollar Million is identified as the independent variable.

Various statistical methods have been employed to conclude the data series. Time series analysis was also carried out to identify the trends over the last twenty two years. And also, Unit Root Test was applied to see the stationary of the series at the level and first difference test by using Augmented Dickey Fuller (ADF) (Shaari, Hong \& Shukeri, 2012; Trung \& Vinh,2011). Regression analysis was conducted to find out the impact of foreign direct investment on economic growth. Further, Cointegration test has been utilized to find out the long run equilibrium relationship between FDI and economic growth rate in terms of real GDP in this study. Finally, Granger causality test is focused in this study to check the causal relationship between FDI and economic growth rate (Shaari, Hong \& Shukeri, 2012).

\section{Result Analysis}

\subsection{Time Series Analysis}

Time series analysis was carried out to identify the trend on foreign direct investment and economic growth and the details are depicted in the diagram. The data on the economic growth is in the percentage. Meantime, the data on the FDI is in the USD Million. Due to that, separate diagrams have been designed to show the trend.

\subsubsection{Foreign Direct Investment and Its Trend in Sri Lanka}

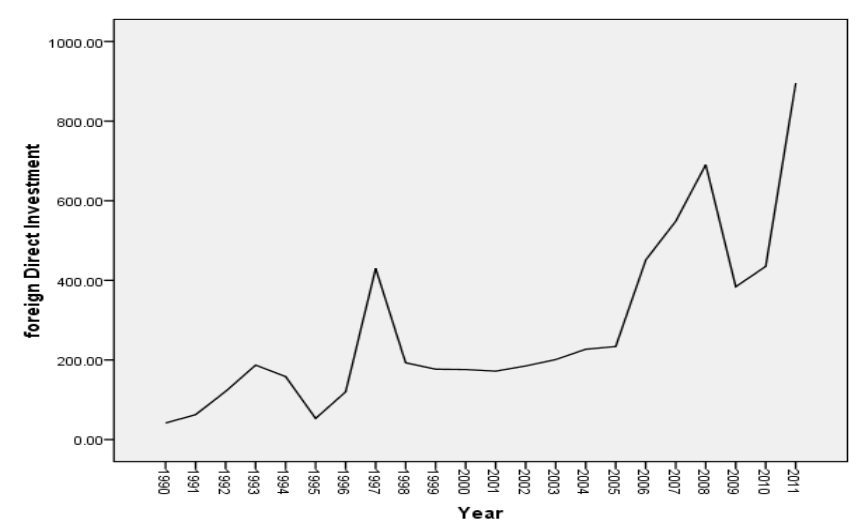

Figure 1. Time Series analysis on FDI

From 1990 to 1993, foreign direct investment in Sri Lanka has been in increasing trend. Later, the increasing trend has been changed. In 1995, the FDI reached to lowest level as 53 USD in Million. After that, the trend in FDI showed the heightening trend.

In 1998, suddenly, FDI has been declined. After that, the period between 1999 to 2005, the FDI trend showed a 
steady growth in terms of USD in Million. Then, form the 2006 to 2008; we have observed the raising trend in FDI. Suddenly, in 2009, the FDI has been diminished. Eventually, the FDI in Sri Lanka was increased in 2010 and 2011. In 2011, Sri Lanka experienced the highest level of FDI in terms of USD in Million as 896, which is considered as the green signal to the prosperity of country. Further, infrastructure development has the greatest share in the FDI in recent years.

\subsubsection{Economic Growth Rate and Its Trend in Sri Lanka}

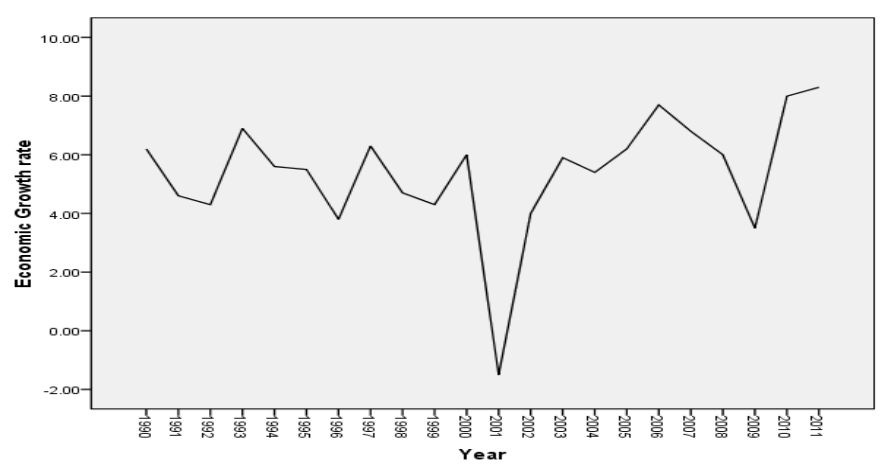

Figure 2. Time series analysis on economic growth

According to the Time series, almost, the economic growth rate was spread between 1 and 7 percentages. Further, in the year 2001, Sri Lanka experienced negative growth rate due to the political instability in the country. After that, the growth rate was increased steadily. And also, in the year 2010, Sri Lankan economy has achieved the highest level of economic growth as 8 percentages.

\subsection{Unit Root Test}

Table 1. Individual unit root test: level

\begin{tabular}{|c|c|c|c|c|}
\hline \multicolumn{3}{|c|}{ Method } & Statistic & Prob.** \\
\hline \multicolumn{3}{|c|}{ ADF - Fisher Chi-square } & 21.8274 & 0.0002 \\
\hline \multicolumn{3}{|c|}{ ADF - Choi Z-stat } & -3.69181 & 0.0001 \\
\hline \multicolumn{5}{|c|}{ Intermediate ADF test results UNTITLED } \\
\hline Series & Prob. & Lag & Max Lag & Obs \\
\hline FDIR & 0.0015 & 1 & 4 & 20 \\
\hline EG & 0.0121 & 0 & 4 & 21 \\
\hline
\end{tabular}

Table 2. Individual unit root test: first difference

\begin{tabular}{|c|c|c|c|c|}
\hline Method & & & Statistic & Prob.** \\
\hline ADF - Fisher Chi-square & & & 15.1791 & 0.0043 \\
\hline ADF - Choi Z-stat & & & -2.75199 & 0.0030 \\
\hline \multicolumn{5}{|c|}{ Intermediate $\mathrm{ADF}$ test results $\mathrm{D}$ (UNTITLED) } \\
\hline Series & Prob. & Lag & Max Lag & Obs \\
\hline D(FDIR) & 0.0830 & 3 & 4 & 17 \\
\hline $\mathrm{D}(\mathrm{EG})$ & 0.0061 & 1 & 4 & 19 \\
\hline
\end{tabular}

Unit Root Test has been applied to check the Panel data for stationary of the series at the level and first difference test with the help of the measure as Augmented Dickey Fuller (ADF). If the test shows the significant level in terms of $p$ value, it will be concluded that the variable series is stationary. It means that, the panel data are not in the position of unit root. In contrast, if the stationary test is not in the significant level in terms of $p$ 
value, it will be statistically explained that the variable series is non-stationary and has a unit root test (Shaari, Hong \& Shukeri, 2012; Trung \& Vinh, 2011).

In the Level test (Table No 1) and in the first difference (Table 2), we have observed that, there is no unit root in the data series. It means that, the variable series is stationary and does not have a unit root test. Therefore, the basic assumption in the econometrics as Unit root is in the validate one.

\subsection{Regression Analysis}

Table 3. Regression analysis

\begin{tabular}{lllll}
\hline Variable & Coefficient & Std. Error & t-Statistic & Prob. \\
\hline FDIR & 0.006713 & 0.007074 & 0.949032 & 0.3539 \\
C & 5.371030 & 0.435444 & 12.33462 & 0.0000 \\
R-squared & 0.043093 & Mean dependent var & 5.386364 \\
Adjusted R-squared & -0.004753 & S.D. dependent var & 2.036172 \\
S.E. of regression & 2.041005 & Akaike info criterion & 4.351270 \\
Sum squared resid & 83.31402 & Schwarz criterion & 4.450455 \\
Log likelihood & -45.86397 & F-statistic & 0.900662 \\
Durbin-Watson stat & 1.731228 & Prob(F-statistic) & 0.353932 \\
\hline
\end{tabular}

In the Regression analysis, the measures like "R-squared" and "S.E. of regression." are viewed as the key aspects in the statistics. Regression accounts for 4.3 percent of the variance in the dependent variable and the estimated standard deviation of the error term is 2.041. Further, Regression model was applied to test that how far the independent variable impact on dependent variable. Coefficient of determination- $\mathrm{R}^{2}$ is the measure of proportion of the variance of dependent variable about its mean that is explained by the independents or predictor variables (Velnampy, 2008).

According to the Regression analysis, there is no significant impact of FDI on economic growth $(\mathrm{F}=0.900 ; \mathrm{P}>$ 0.05). It means that, economic growth is not contributed by the FDI significantly. Meanwhile, the 4.3 percentage of impact was found and, the constant value has the significant level $(\mathrm{P}<0.05)$. It means that, economic growth is mainly contributed by other factors significantly. A Durbin-Watson close to 2.0 is consistent with no serial correlation, while a number closer to 0 means there is, probably, serial correlation. In our study, DW has the value as 1.731 which is closer to 2.0 , So that there is no serial correlation between the variables which have been used in this study.

\section{Hence the $H_{1}$ is rejected.}

\subsection{Co integration Test}

Co integration test has been focused to find out the long run equilibrium relationship between FDI and economic growth rate in terms of real GDP in this study. It means that, how FDI in the long run react to economic growth rate.

Table 4. Unrestricted cointegration rank test (trace)

\begin{tabular}{ccccc}
\hline $\begin{array}{c}\text { Hypothesized } \\
\text { No. of CE(s) }\end{array}$ & Eigenvalue & $\begin{array}{c}\text { Trace } \\
\text { Statistic }\end{array}$ & $\begin{array}{c}0.05 \\
\text { Critical Value }\end{array}$ & Prob.** \\
\hline None * & 0.496957 & 17.40306 & 15.49471 & 0.0255 \\
At most $1 *$ & 0.204569 & 4.348552 & 3.841466 & 0.0370 \\
& Unrestricted Cointegration Rank Test (Maximum Eigenvalue) \\
Hypothesized & \multicolumn{5}{c}{ Max-Eigen } & 0.05 & \\
No. of CE(s) & Eigenvalue & Statistic & Critical Value & Prob.** \\
None & 0.496957 & 13.05451 & 14.26460 & 0.0770 \\
At most $1 *$ & 0.204569 & 4.348552 & 3.841466 & 0.0370 \\
\hline
\end{tabular}


According to the Co integration test, the both maximum-Eigen statistic and trace statistic are used to conclude the data on the FDI and Economic growth in the Sri Lankan context. Further, the trace statistic value is 17.40306 higher than the critical value (trace) 15.49471 at five percent significant level. This trace statistic result indicates that there is a long run relationship between two variables at five percent significant level. Further, Max-Eigen statistic is 13.05451, less than critical value (Eigen) 14.26460 at five percent significant level. But, At most $1 *$ level, Max-Eigen statistic is 4.348552, higher than critical value (Eigen) 3.841466 at five percent significant level. Overall, in the Sri Lankan context, there is a long run equilibrium relationship between FDI and economic growth rate. In contrast, based on the regression analysis, Regression accounts for 4.3. Percent of the variance in the dependent variable, which is not in the significant at five percent. And the estimated standard deviation of the error term is 2.041. Meantime, the influence or impact percent is in the lowest level in terms of percentage (4.3\%). Further. Scholars in the econometrics pointed that, regression analysis is not in the statistical position to give insights in terms of long run relationship, causal relationship among time series data (Athukorala, 2013).

Therefore, $\mathrm{H}_{2}$ is accepted.

4.5 Granger Causality Test

Granger causality test is utilized to check the causal relationship between two variables. Generally, the time series should be checked before running the causality test by applying the unit root and the co integration test.

Table 6. Pair wise granger causality tests

\begin{tabular}{llll}
\hline Null Hypothesis: & Obs & F-Statistic & Probability \\
\hline EG does not Granger Cause FDIR & 20 & 0.06836 & 0.93422 \\
FDIR does not Granger Cause EG & & 0.33218 & 0.72250 \\
\hline
\end{tabular}

According to the Granger causality test, economic growth does not granger cause foreign direct investment and foreign direct investment also does not granger cause economic growth rate. It means that, the two variables are not mutually correlated.

Therefore, $\mathrm{H}_{3}$ is rejected.

\section{Conclusion and Results}

Based on the overall study findings, we conclude that, there is no significant impact of FDI on the economic growth, which is in lowest level. Only 4.3 percent of the variance in the dependent variable has been found. In contrast, we found that, in the Sri Lankan context, there is a long run equilibrium relationship between FDI and economic growth rate. Statistical findings on the basic regression analysis, Cointegration test and Granger causality test show the contradiction in terms of the findings. Finding of the Regression analysis pointed that, there is no significant influence of FDI on economic growth; also the influence rate in terms of percentage is viewed as the humblest or lowest one. In contrast, finding related to the Co integration stated that, both variables as FDI and economic growth rate are associated in the long term context. Meantime, scholars in the econometrics stated that, Co integration test generally is applied among time series data. Due to that, Co integration test gives the insights to the findings in terms of long run view, supportive way. Balamurali and Bogahawatte (2004) noted that, FDI is a key determinant of Sri Lankan economic growth after the 1977 period. The empirical results suggest that one long-run equilibrium relationship exists between FDI and economic growth.

Some studies on FDI and economic growth in developing and developed counties showed the positive influence between FDI and Economic Growth (Ram \& Zhang, 2002; Blomstom, Lipsey \& Zejan, 1994; Borensztein, Gregorio \& Lee, 1998). In contrast, Carkovic and Levine (2002) have found the insignificant influence. Further, Dutt (1977) has found that, there is a significant negative impact of FDI on economic growth. Even though, various international organizations and foreign advisors suggested that developing countries should focus primarily on foreign direct investment (FDI) as a source of external finance. Generally, FDI induces economic growth more than other types of capital inflows.

The benefits of the FDI are as follows:

- New technologies and Methods are brought to developing countries and new employment opportunities are created by the FDI. 
- $\quad$ provide the opportunities to establish the strategic collaboration with multinational companies; foreign earning can be increased through the export expansions

- $\quad$ Resources in the developing countries can be utilized in the effective and efficient ways.

- Domestic economy should be linked with foreign economy to utilize resources in the local.

Sri Lankan Government and central bank of Sri Lanka should focus on the infrastructure development through FDI to get the sustainable growth in the long term view. In recent years, data on Sri Lanka's FDI inflows reveals that about 59 percent came into infrastructure development projects. This should be considered as the green signal to the prosperity of the country, while manufacturing and services sectors attracted about 31 percent and 9 percent respectively. Further, in 2011, a noticeable change has been observed in sector-wise composition of FDI inflows. 20 percent share has been attracted by the Hotels and restaurant sector. Meantime, 18 percent share was fulfilled by the Telecommunication sector. Inflows to Hotels and restaurant sector were brought in by several prominent international hotel companies intending to cash in on the postwar tourism boom (Central Bank Reports, Sri Lanka, 2010, 2011, 2012).

Especially, the Sri Lankan Government should take the necessary actions to get the financial system stability in terms of Domestic stability and stability in exchange rate to utilize the potential benefits from FDI. Due to that, the Fiscal and Monetary policy should be framed to attract the FDI by the Central Bank, Sri Lanka in an effective and efficient way. Meantime, FDI should be directed to the agricultural activities to get the food sufficient in the domestic level. Further, tourism and hotel management, education and research and developments should be considered, when the government gives the benefits in terms of infrastructure developments, concessions etc in the international trade policies.

\section{References}

Alfaro, L., Chanda, A., Kalemli-Ozcan, S., \& Sayek, S. (2003). FDI Spillovers, Financial Markets and Economic Development (EPub). International Monetary Fund.

Athukorala, A. W. (2003). The Impact of Foreign Direct Investment for Economic Growth: A Case Study in Sri Lanka: 9th International conference on Sri Lanka Studies, 2003, Matara, Sri Lanka.

Balamurali, N., \& Bogahawatte, C. (2004). Foreign Direct Investment and Economic Growth In Sri Lanka, Sri Lankan. Journal of Agricultural Economics, 6(1).

Blomstrom, M., Lipsey, R. E., \& Zejan, M. (1994). What explains the growth of developing countries? Convergence of productivity: Cross-national studies and historical evidence, 243-259.

Blomstrom, M., Lipsey, R. E., \& Zejan, M. (1994). What explains developing country growth? (No. w4132). National Bureau of Economic Research.

Borensztein, E., De Gregorio, J., \& Lee, J. W. (1998). How does foreign direct investment affect economic growth? Journal of international Economics, 45(1), 115-135. http://dx.doi.org/10.1016/S0022-1996(97)00033-0

Buckley, P. J., \& Casson, M. (1976). The future of the multinational enterprise (Vol. 1). London: Macmillan. http://dx.doi.org/10.1057/palgrave.jibs.8490006

Buckley, P. J., \& Casson, M. C. (1998). Analyzing foreign market entry strategies: Extending the internalization approach. Journal of International Business Studies, 539-561.

Buthe, T., \& Milner, H. V. (2008). The politics of foreign direct investment into developing countries: increasing FDI through international trade agreements? American Journal of Political Science, 52(4), 741-762. http://dx.doi.org/10.1111/j.1540-5907.2008.00340.x

Carkovic, M., \& Levine, R. (2002). Does foreign direct investment accelerate economic growth? U of Minnesota Department of Finance Working Paper.

Contessi, S., \& Weinberger, A. (2009). Foreign direct investment, productivity, and - country growth: an overview. Federal Reserve Bank of St. Louis Review, 91(2), 61-78.

Denisia, V. (2010). Foreign Direct Investment Theories: An Overview of the Main FDI Theories. European Journal of Interdisciplinary Studies, 2(2), 104-110.

Dunning, J. H. (1988). Explaining international production (p. 80). London: Unwin Hyman.

Dutt, S. (1977). With Nehru in the Foreign Office. Minerva Associates (Publications). Global investment trend monitor, 2013: Global FDI recovery derails, United Nations Conference on Trade and Development. 
Hearth, S. P. (n.d.). Impact of Trade Liberalization on economic growth of Sri Lanka: An Econometric Investigation. Faculty of Business studies and finance, Wayamba University of SriLanka

Hennart, J. F. (1982). A theory of multinational enterprise (pp. 5-6). Ann Arbor: University of Michigan Press.

Hennart, J. F. (1988). A transaction costs theory of equity joint ventures. Strategic management journal, 9(4), 361-374. http://dx.doi.org/10.1002/smj.4250090406

Hymer, S. (1976). The international operations of national firms: A study of direct foreign investment (Vol. 14, pp. 139-155). Cambridge, MA: MIT press.

Khaliq, A., \& Noy, I. (2007). Foreign direct investment and economic growth: Empirical evidence from sectoral data in Indonesia. Retrieved from http://www. economics.hawaii.edu/research/workingpapers/WP_07-26. pdf

Nunnenkamp, P., \& Spatz, J. (2002). Determinants of FDI in developing countries: Has globalization changed the rules of the game? Transnational Corporations, 11(2)

Organisation for Economic Co-operation and Development. (2002). Frascati Manual 2002: Proposed Standard Practice for Surveys on Research and Experimental Development. OECD.

Ram, R., \& Zhang, K. H. (2002). Foreign Direct Investment and Economic Growth: Evidence from Cross - Country Data for the 1990s. Economic Development and Cultural Change, 51(1), 205-215. http://dx.doi.org/10.1086/345453

Shaari, M. S. B., Hong, T. H., \& Shukeri, S. N. (2012). Foreign Direct Investment and Economic Growth: Evidence from Malaysia. International Business Research, 5(10), 100. http://dx.doi.org/10.5539/ibr.v5n10p100

Tuong, P. V. (2011). Development of special economic zones, industrial estates, ports, metropolis and alternative roads in the greater Ho Chi Minh City area. Intra-and inter-city connectivity in the Mekong region. BRC Research Report, 6 .

Velnampy, T. (2008). Job Attitude and Employees Performance of Public Sector Organizations in Jaffna District, Sri Lanka. GITAM Journal of Management, 6(2), 66-73.

Velnampy, T., \& Achchuthan, S. (2013a). Fiscal Deficit and Economic Growth: A Study on Sri Lankan Economic Perspective. Developing Country Studies, 3(3), 166-174.

Velnampy, T., \& Achchuthan, S. (2013b). Export, Import and Economic Growth: Evidence from Sri Lanka. Journal of Economics and Sustainable Development, 4(9), 147-155.

Vernon, R. (1966). International investment and international trade in the product cycle. The Quarterly Journal of Economics, 190-207. http://dx.doi.org/10.2307/1880689

\section{Copyrights}

Copyright for this article is retained by the author(s), with first publication rights granted to the journal.

This is an open-access article distributed under the terms and conditions of the Creative Commons Attribution license (http://creativecommons.org/licenses/by/3.0/). 